\title{
Memória: da filosofia à neurociência
}

\author{
João Marcos Ferreira Cantarino ${ }^{I}$ \\ Danilo Assis Pereira ${ }^{2}$
}

\begin{abstract}
RESUMO - Este trabalho visa a realizar revisão bibliográfica sobre a memória, no que diz respeito aos seus aspectos filosóficos, psicológicos e neurocientíficos. Apresenta, primeiramente, as teorias filosóficas sobre a memória e seus principais postuladores. A seguir, mostra de que forma a psicologia vê a memória, apresentando as principais contribuições que os estudos psicológicos deram ao entendimento do assunto. Então, expõe de que forma a dicotomia mente versus corpo está ultrapassada nos dias atuais, principalmente em face das novas descobertas em neurociência, procurando deixar claro que o entendimento do processo mental só é possível com o conhecimento de seus correlatos neurais. Finalmente, dedica-se a apresentar as principais descobertas da neurociência sobre a memória, procurando mostrar como é possível aos neurocientistas refutar ou confirmar, empiricamente, as teorias e hipóteses levantadas sobre o funcionamento dos diversos tipos de memória.
\end{abstract}

Palavras-chaves: memória, filosofia, psicologia, neurociência, cognição

\section{Memory: from philosophy to neuroscience}

\begin{abstract}
This work aims at presenting a bibliographical revision on the subject memory, as it is viewed by philosofy, psychology and neuroscience. It brings, first, the philosophical theories on the memory and its main theoriticians. Then, it shows how memory is seen by psychologists, presenting the main psychological theories on this subject. Later it displays why the dichotomy mind versus body is nowadays exceeded, due mainly to the new discoveries in neuroscience. Finally, discourses on the neuroscientific studies of memory, looking for to show how it is possible to neuroscientists to refute or to confirm, empirically, the theories and hypotheses raised on the functioning of the memory.
\end{abstract}

Key words: memory, philosophy, psychology, neuroscience, cognition

Monografia apresentada na conclusão de curso de Psicologia do UniCEUB.

${ }^{1}$ Graduando em Psicologia pelo UniCEUB. E-mail: joao.cantarino@camara.gov.br

2 Orientador de monografia. Professor de Psicologia do UniCEUB. E-mail: danilo.assis@uniceub.br 
Desde sempre, o homem é fascinado pelo tempo. A força da idéia de um tempo passando eternamente é tamanha que não surpreende existir um deus do tempo em quase todas as religiões mitológicas, honra igualmente conferida somente ao Sol, à Lua e à Terra. (Eliade, 1998)

O tempo fascina e amedronta. Cronos, o pai de todos os deuses gregos, comprazia-se em devorar os próprios filhos. A imagem não poderia ser mais clara: o homem é criado e consumido por seu próprio tempo.

Domar essa força sempre foi um sonho. De Zeus, que engana Cronos, seu pai, e o mata, passando pelo desejo onipresente de uma máquina do tempo, até o Super-Homem, que faz a Terra girar ao contrário para trazer de volta à vida a mulher amada, o homem sempre acalentou dominar o tempo todo-poderoso.

Mas, a seta do tempo parece seguir sempre em frente, desdenhosamente em direção ao futuro, deixando atrás de si nada além da escuridão do passado. A unidireção temporal é uma das mais fundamentais leis da natureza. Neste canto do Universo, governa todos os acontecimentos, sejam geológicos, biológicos ou psicológicos. Galáxias e estrelas nascem e morrem, criaturas vivas são jovens e, depois, envelhecem, as causas precedem os efeitos, não há como voltar ao dia de ontem. A passagem do tempo é irreversível.

Não seria realmente incrível se houvesse exceção, um caso especial, algum mecanismo que conseguisse opor-se a essa força onipresente que governa a tudo e a todos? Há, no ser humano, dispositivo capaz de mover para trás as engrenagens do mundo e trazer de volta o passado, de reviver o vivido, de transformar o ontem em hoje. Essa verdadeira maravilha da natureza é a memória. Mas, como a natureza faz isso? Há milênios, o homem persegue a resposta.

Diante dos mistérios, o animal santarrão - como Freud definiu o homem tende a criar mitos e deuses. Mitos e deuses foram criados para explicar a memória. Com o surgimento da filosofia na Grécia, as primeiras tentativas solucionar o mistério com explicações racionais tomaram forma, primeiramente, com Platão, depois, com Aristóteles. As bases conceituais sobre a memória lançadas por esses dois grandes filósofos são, ainda hoje, válidas.

O lingüista norte-americano Noam Chomsky afirma que muito contribui para a ciência um estudo que tira os eventos pesquisados da categoria de milagres para situá-los na classe dos problemas. (Pinker, 2004) É exatamente isso o que acontece com o estudo da memória. Há cada vez menos milagres. Em compensação, os problemas parecem intermináveis.

Modernamente, pode-se pensar o estudo da memória humana como uma batalha com duas frentes, interligadas, porém distinguíveis e independentes. De um lado, está a pesquisa voltada à fisiologia cerebral, sua matéria e partes 
constituintes. Tal estudo é campo precípuo de neurologistas, biólogos, neurofisiologistas, bioquímicos. De outro lado, há aqueles que estão mais interessados em descobrir como se dá, a partir da atividade cerebral, a representação dos dados memorizados. Entra-se aqui na seara da psicologia cognitiva, a ciência da mente.

É tradição secular definir a parte material do encéfalo como cérebro; ao resultado da atividade cerebral, dá-se o nome de mente. Em outras palavras, a mente é aquilo que o cérebro faz, é o produto da atividade cerebral. (Pinker, op. cit.) $\mathrm{Na}$ definição do filósofo John Searle, é "a capacidade especial do cérebro que o faz diferir notavelmente de todos os outros órgãos biológicos, de produzir e sustentar toda enorme multiplicidade de nossa consciência de vida". (Searle, 1997, p. 185) Esses produtos cerebrais são tudo aquilo que difere o ser humano dos outros animais, seja pela exclusividade, seja pela complexidade. Uma lista breve dos produtos cerebrais incluiria, além da memória, a percepção, a linguagem, o pensamento e a emoção.

Dos processos mentais, a memória é aquele sobre o qual os estudos parecem estar mais avançados. Milhões de dólares são investidos anualmente na busca para entender a memória. Por quê? Por que entender a memória é tão importante para nós?

Não é difícil chegar à resposta a esta pergunta. A questão não é apenas poder recordar o que aconteceu antes para o regozijo de agora. Não há dúvida de que isso é importante, mas a resposta vai além disso. Depende diretamente do funcionamento da memória a aquisição de todas as informações e habilidades que possamos ter na vida. Sem memória, não há conhecimento nem habilidades. Toda vez que se lembra de um fato do passado confia-se na capacidade da memória; logo, sem memória, não haveria passado. Se alguém vai ao supermercado cantarolando uma canção, e, no caminho, reconhece alguns amigos, isso só é possível porque memorizou e lembrou o caminho, a canção e os amigos. Na verdade, saber que alguém é amigo ou não depende de que se lembre do comportamento do outro no passado. Possuir lembranças é importante também para que haja autoconsciência, pois, em certo sentido, o ser humano é o resultado de suas memórias. Aquilo que se chama de "eu" não é senão o conjunto das memórias que se carrega na vida.

Em uma das cenas mais marcantes do clássico Blade Runner (recentemente eleito por 300 dos mais eminentes cientistas do mundo, em pesquisa feita pelo jornal britânico The Guardian, como o melhor filme de ficção científica de todos os tempos) a personagem Rachel, vivida por Sean Young, descobre que não é um ser humano, mas um robô, um andróide tão perfeito que consegue enganar a qualquer um, inclusive a si mesma. Atônita, tenta convencer os policiais de que estão errados, de que ela é sim um ser humano e apresenta, como prova, suas memórias, que 
remontam à infância. Um dos policiais, então, explica-lhe que, para que os andróides tenham um sentido de "eu", têm memórias de pessoas reais implantadas em seus cérebros eletrônicos, e que, no caso dela, as memórias pertenciam à sobrinha de um dos donos da empresa que a criou.

O caso descrito acima é ficção, mas a vida real está cheia de pessoas que não sabem quem são porque perderam a memória. Podem ser citados dois exemplos famosos na história da psicologia: o caso "H.M", estudado pela psicóloga Brenda Milner, e o caso "David”, relatado pelo neurocientista português António Damásio5. Ambos os pacientes sofreram lesões na região medial temporal - o primeiro, em decorrência de cirurgia contra epilepsia, e o segundo, em razão de acidente vascular - e, como consequiência, perderam a memória retrógrada, além de não mais conseguirem memorizar fatos novos. Tanto para "H.M." quanto para "David", a falta de memórias resultou em efeitos devastadores na vida prática, como a destruição da vida social, principalmente, porque perderam o sentido de si mesmos e dos outros, uma vez que isso é dado no presente, em razão dos acontecimentos do passado. Igualmente trágica é a situação dos portadores do mal de Alzheimer, doença que, de acordo com Kandel, Schwartz \& Jessell (2000), afeta cerca de 7\% das pessoas com mais de 65 anos e $40 \%$ dos idosos acima de 80 anos.

Como resultado desse grande interesse pela memória, impressiona a extensão da literatura sobre o assunto. São milhares de pesquisas e artigos publicados com os mais diferentes focos. Em alguns, o interesse é descobrir como as informações são adquiridas. Em outros casos, como são guardadas. Outros, ainda, querem saber como os dados são recuperados, ou que partes do cérebro estão envolvidas nos processos para memorização, ou por que alguns fatos e objetos são mais passíveis de serem lembrados que outros, e assim por diante. Mesmo diante da vasta literatura, percebeu-se a escassez, ou a ausência, de obras que fossem voltadas ao público da psicologia ou das ciências cognitivas em geral, e que trouxessem, em conjunto, as três principais dimensões sob as quais a memória humana é estudada: a filosófica, a psicológica e a neurocientífica.

Assim, a intenção primeira deste trabalho é buscar preencher a lacuna encontrada na literatura sobre a memória. Para tanto, será apresentada a primeira visão do homem sobre a memória, ou seja, a visão filosófica. A seguir, expõem-se as principais contribuições da psicologia para o estudo da memória, principalmente quanto aos aspectos conceituais e taxionômicos. Mostra-se, desse modo, que a antiga dicotomia entre mente e corpo está ultrapassada. Passa-se, por fim, à reflexão sobre a neurociência estudar a memória e os resultados desse estudo. 


\section{Memória e filosofia}

\section{Por que a memória é assunto da filosofia?}

A filosofia, como a entendemos no Ocidente, nasceu na Grécia Antiga. Surgiu como algo que se desgarrou da narrativa mitológica e que acabou voltando-se contra ela. Segundo May (1992), um mito é um modo de dar sentido ao mundo sem sentido. Da mesma forma, Campbell (1991, p. 3) definiu-o como "qualquer história humana de um ser humano em busca de um sentido". Para efeito de contraposição com a filosofia grega, porém, os mitos são melhor definidos como "narrativas sobre o nascimento, criação, vida e morte dos povos, do mundo, as aventuras dos antepassados, seu contato com os deuses ou a própria vida deles e, enfim, o que virá pela frente". (Ghiraldelli Jr., 2002)

A filosofia é uma conversação e, também, uma narrativa sobre tudo isso. Todavia, quando se colocou contra os mitos, o fez mostrando que não eram boa explicação do que pretendiam explicar. Assim, a filosofia nasceu autoproclamandose uma atividade de explicação do mundo, e relegando o mito à atividade narrativa incapaz de fazê-lo ou o mito explicaria o mundo de modo ingênuo, falso, talvez até mentiroso (a mentira é a falsidade intencional). E por quê? Porque os mitos não seguiam, nas narrativas, a cadeia dada por causas e efeitos nem por razões.

A filosofia, ao contrário, seria a verdadeira explicação do mundo, uma explicação racional, isto é, com a razão e pela razão. Ainda de acordo com Ghiraldelli, a filosofia apresentou-se ser a atividade de reflexão racional sobre o mundo. Se o mito não era uma explicação, e se a filosofia é que era a explicação do mundo, iniciava-se, então, com uma pergunta descabida para o mito: o que é a realidade?

Num resumo máximo do que ensinam Padovani e Castagnola (1967), os gregos antigos obtiveram dupla resposta para "o que é a realidade?": o real é physis (natureza); o real é o ser (essência). A primeira resposta proveio da Jônia e fundou a filosofia como atividade específica: a filosofia é cosmologia. A segunda resposta veio de Eléia e traçou os rumos da filosofia como ontologia e metafísica.

Cosmologia, ontologia e metafísica foram, portanto, as três primeiras grandes áreas - ou problemas - da filosofia. Com o passar do tempo e o advento de filósofos como Sócrates, Platão e Aristóteles, outros problemas filosóficos foram levantados, como a ética, a estética e a política. Mas, por trás de todos esses problemas, escondiase outro que se revelou crucial. Conforme salienta Durant (1996), para que os filósofos entendessem o mundo, fazia-se necessário entender a natureza do homem. Estava fundada a psicologia.

Aristóteles afirmou que a psicologia se preocupa com "a natureza, a substância 
e as determinações acidentais do homem". (apud Abbagnano, 2000, p. 809) Uma das características fundamentais da natureza do homem é sua capacidade de adquirir conhecimento. Para se entender a psicologia do homem, foi necessário, então, que se formulasse uma teoria do conhecimento, ou gnosiologia.

Segundo Modin (1980), a gnosiologia é a parte da filosofia que tenta responder à seguinte questão: “como chegamos a conhecer?". Estão compreendidas na gnosiologia as preocupações filosóficas com a percepção, a imaginação, a linguagem, o pensamento, a consciência e a memória. Entender a memória é, portanto, passo fundamental para que se entenda o homem, sem isso, é impossível que se entendam a realidade, o princípio e o fim da filosofia.

\section{A memória na Antigüidade Clássica}

Na mitologia grega, a memória era representada pela deusa Mnemosyne, mãe das Musas, que protegem as Artes e a História. De acordo com Schwab (1997), a deusa Memória dava aos poetas e adivinhos o poder de voltar ao passado e de lembrá-los à coletividade. Tinha, também, poder de conferir imortalidade aos mortais, pois, quando o artista ou o historiador registram em suas obras a fisionomia, os gestos, os atos, os feitos e as palavras de um humano, nunca serão esquecidos e, por isso, tornam-se memoráveis. Os artistas e historiadores pediam às Musas que protegessem as obras escritas para que não fossem perdidas as realizações memoráveis dos humanos e para que servissem de exemplo às gerações futuras. Dessa forma, a memória era considerada inseparável da experiência do tempo como algo que escoa e passa.

Além da poesia e da história, também a medicina valia-se dos poderes da deusa da memória. Um aforismo, atribuído a Hipócrates, o pai da medicina, afirmava que a vida é breve, a arte é longa, a ocasião escapa, o empirismo é perigoso e o raciocínio é difícil. É preciso não só fazer o que convém mas também ser ajudado pelo paciente. Para tanto, os médicos gregos utilizavam-se de um expediente que chegou aos dias atuais: a anamnese.

Ao lado de imortalizar os mortais e de auxiliar a arte médica, para os antigos, a memória ainda possuía outra função. Os romanos desenvolveram uma arte chamada eloqüência ou retórica, destinada a persuadir e a criar emoções nos ouvintes, por meio do uso belo e eficaz da linguagem. Nesse aprendizado, consideravam a memória indispensável, não só porque o bom orador, poeta, político, advogado, era aquele que falava ou pronunciava longos discursos sem ler e sem apoiar-se em anotações como também porque o bom orador era aquele que aprendia de cor as regras fundamentais da eloqüência ou oratória. 
Como a memória fosse considerada essencial ao aprendizado, os mestres de retórica criaram métodos de memorização, ou "memória artificial", que constituíam a "arte da memória", parte central do ensino e do aprendizado de oratória, usada, depois, por outras disciplinas. Os romanos julgavam, portanto, que além da memória natural, os seres humanos são capazes de desenvolver outra memória que amplia e auxilia a memória espontânea. Justificavam a "arte da memória" ao contar uma lenda sobre o criador da retórica, o poeta grego Simônides de Céos.

Conforme narrado por Yates (1966), em um banquete dado pelo rei de Tessalônica, Scopas, o poeta Simonides de Ceos declamou um poema lírico em honra de seu anfitrião e pediu o pagamento por ele. Mas, como o poema também incluía passagem em homenagem aos deuses gêmeos Cástor e Pólux, o rei disselhe que pagaria apenas a metade e que Simonides fosse pedir a outra metade a Cástor e Pólux. Pouco depois, um mensageiro aproximou-se de Simonides dizendolhe que dois jovens o procuravam do lado de fora do palácio. Enquanto estava no jardim, o palácio desabou, e todos morreram. Os dois jovens eram Cástor e Pólux. O poema estava pago. As famílias dos demais convidados desesperaram-se porque não conseguiam reconhecer seus mortos. Simonides, porém, lembrava-se dos lugares e das roupas de cada um e pôde ajudar a identificação dos mortos.

A lembrança do palácio e dos lugares dos convidados levou à criação da "arte da memória" como um palácio com lugares nos quais colocamos imagens e palavras e, passeando por ele, ordenadamente, recordamos as coisas, as pessoas, os fatos e as palavras necessárias para escrever e dizer discursos, poesias, peças teatrais. Não por acaso, santo Agostinho, em trecho famoso de suas Confissões, refere-se aos "campos e vastos palácios da memória". (apud Chauí, 1995, p.125)

\section{Os filósofos e a memória}

De acordo com Abbagnano (op. cit.), as primeiras referências filosóficas à memória são encontradas em Platão (c. 427-c.347 a.C.), que, no diálogo Philebus, distinguiu dois momentos do processo mnemônico: a conservação de sensações e a reminiscência. Esses termos, posteriormente, também foram utilizados por Aristóteles.

Aristóteles (384-322 a.C.), porém, foi além ao explicar que tanto a retenção quanto a recordação - os dois momentos platônicos - são inteiramente físicos. Ainda segundo Abbagnano, o grande pensador de Estagira asseverou que a retenção era decorrente do movimento, e a recordação, ao contrário, seria uma espécie de dedução, pois "quem recorda deduz que já escutou ou percebeu aquilo de que se lembra: isso é uma espécie de busca”. (id. Ibid., p. 657) 
Outro filósofo grego, Plotino (205-270), buscou refutar Aristóteles, negando o caráter físico da memória em favor de uma concepção mística. De acordo com Padovani e Castagnola (op. cit.), Plotino postulava que a memória se localizava na alma, e não no corpo, e que este era, na verdade, um obstáculo para a retenção de imagens. Essa visão mística da memória é a mesma que seria adotada na Idade Média por Santo Agostinho (354-430) e São Tomás de Aquino (1225-1274), já que, para ambos, a memória era o local na alma destinado à conservação do homem.

Abbagnano ressalta que a concepção medieval da memória como mecanismo de conservação foi retomada na era moderna, primeiramente com Leibniz (16461716), que a via como a conservação integral do mundo sob forma virtual. Mas, foi o francês Henry Bérgson (1859-1941) considerado o autor da mais sólida obra filosófica no que diz respeito à memória. O prêmio Nobel de Literatura em 1927 era um filósofo espiritualista, o que significa dizer que sua filosofia se preocupava com as "atividades espirituais não redutíveis à razão, às quais se atribui um alcance metafísico". (Modin, 1983, p. 127) Procurou contrapor-se à idéia da memória como mecanismo baseado na recordação ao afirmar que "a memória não consiste na regressão do presente para o passado, mas, ao contrário, no progresso do passado ao presente". (Abbagnano, op. cit., p. 658) Para ele, lembrar é partir de um estado virtual rumo ao ponto que se transforma em estado presente e agente, ou seja, até o plano extremo de consciência sobre o qual se desenha o corpo de quem lembra. A esse estado de consciência Bergson chamou de recordação pura. Em conseqüência da não aceitação da memória como mecanismo de recordação, a recordação pura não tinha bases físicas. Isso não significa que os distúrbios das funções mnemônicas apagam as memórias, mas que o mecanismo físico, ou seja, a recordação está falha de alguma forma.

Outros filósofos, ao contrário de Bergson, basearam suas teorias da memória no fenômeno da recordação. Thomas Hobbes (1588-1679), por exemplo, definiu-a como "a sensação de já ter sido", o que, fundamentalmente, significa defini-la, em relação ao ato de reconhecer naquilo que se percebe, o que já se percebeu outra vez. Houve os que preferiram ressaltar o caráter ativo da memória, a exemplo de Locke (1632-1704) e Kant (1724-1804), para quem todo o conhecimento humano a memória, inclusive - jamais poderia ser passivo, uma vez que o objeto está sempre à mercê da vontade do ser humano.

Vale a pena ainda mencionar dois pontos de vista filosóficos que tiveram grande influência sobre a psicologia da memória. O primeiro deles interpreta a memória como inteligência ou pensamento, e tem como maior expoente o alemão Georg Wilhelm Friedrich Hegel (1770-1831). Para os hegelianos, a memória é o pensamento exteriorizado, o pensamento que encontra um objeto externo. O outro é aquele que vê a memória como um mecanismo associativo e foi expresso pela primeira 
vez por Spinoza (1632-1677), teorizado com mais profundidade por Hume (17111776).

Grande parte da psicologia moderna baseou seus estudos em memória na hipótese associacionista, até que, segundo Abbagnano, a psicanálise e a psicologia da Gestalt mostrassem a importância da atitude volitiva no ato de recordar. Isso, de certa forma, retoma os pressupostos de Kant e Locke.

\section{Memória e teoria do conhecimento}

Conforme Hegel (1991), o conhecimento tornou-se um problema para a filosofia a partir da disputa entre os sofistas e Sócrates. Para os primeiros, o Ser jamais pode ser conhecido. Sobre ele, têm-se apenas opiniões subjetivas. Já Sócrates afirmava que o Ser é conhecível, mas, para isso, os homens têm de afastar da vista as ilusões dos sentidos, das palavras e das opiniões.

Mas, foi somente a partir do século XVII que a teoria do conhecimento, ou gnosiologia, tornou-se realmente uma doutrina, principalmente com as obras de Francis Bacon, René Descartes e John Locke. Segundo Chauí, esses autores sistematizaram a teoria do conhecimento, de acordo com a qual a memória possui as seguintes funções: retenção de um dado da percepção, da experiência ou de conhecimento adquirido; reconhecimento e produção do dado percebido, experimentado ou conhecido numa imagem, que, ao ser lembrada, permite estabelecer relação ou nexo entre o já conhecido e os novos conhecimentos; recordação ou reminiscência de algo como pertencente ao tempo passado e, enquanto tal, diferente ou semelhante a algo presente; capacidade para evocar o passado a partir do tempo presente ou de lembrar o que já não é por meio do que é atualmente. Por essas funções, a memória é considerada essencial para a elaboração da experiência e do conhecimento científico, filosófico e técnico. Aristóteles escreveu que "é da memória que os homens derivam a experiência, pois as recordações repetidas da mesma coisa produzem o efeito duma única experiência”. (apud, Chauí, op. cit.)

A teoria do conhecimento dá grande importância ao caráter subjetivo da memória, ou seja, a importância do fato e da coisa é relativa ao significado emocional ou afetivo do fato ou da coisa para cada um. O modo como algo impressiona e fica gravado depende da necessidade para a vida, do prazer ou da dor que um fato ou algo produziram, etc. Em outras palavras, mesmo que o cérebro grave e registre tudo, isso não é a memória, e, sim, os sentidos e os significados daquilo que foi gravado.

Para a filosofia, a memória não é apenas recordar, mas uma das formas fundamentais da existência humana, a relação do ser humano com o tempo, o que 
vale dizer, com o tempo passado. A memória é, portanto, a presentificação do que já passou, e é a marca do agora que virará passado na lembrança. Dessa forma, a memória é o próprio passado, pois é ela que o faz existir.

\section{A memória como um processo psicológico}

\section{A psicologia, o estudo da memória e a revolução cognitiva}

As discussões dos filósofos gregos sobre a natureza e a origem do conhecimento desenvolveram-se em debate que já dura milhares de anos. Dessas discussões, nasceram dois grandes posicionamentos: o empirismo, que sustenta que todo conhecimento provém da experiência, e o nativismo, que afirma que os seres humanos vêm ao mundo com grande parcela de conhecimento inato. O debate intensificou-se nos séculos XVII, XVIII e XIX, contrapondo, de um lado, filósofos, como Locke, Berkeley, Hume e Mill, defensores do empirismo, e, de outro, Hobbes, Descartes e Kant, que propunham a visão nativista.

Durante os longos anos desse debate, ciências, como astronomia, física, química, biologia e paleontologia, tiveram desenvolvimento impressionante. $\mathrm{O}$ corpus da mecânica clássica, por exemplo, foi, praticamente, todo construído por Galileu e Newton, que nasceram no século XVI e XVII, respectivamente, com base no uso rigoroso do método científico, do qual foram pioneiros. Enquanto isso, o estudo da cognição humana permaneceu estacionado até o século XIX. Por quê?

Não se pode colocar a culpa desse atraso nas barreiras técnicas e conceituais. Conforme salienta o psicólogo americano John Anderson, muitos experimentos em psicologia cognitiva poderiam ter sido empreendidos e realizados já no tempo dos gregos. (Anderson, 2004) Mas, a psicologia cognitiva, assim como outras ciências que têm os humanos como objeto de estudo, sofreu com a atitude egocêntrica, chauvinista, mística e confusa que nós temos sobre nós mesmos e sobre nossa natureza. Até o século XIX, parecia inconcebível que o funcionamento da mente pudesse ser estudado tal como se estuda qualquer outro fenômeno natural.

Por causa disso, a psicologia cognitiva, como ciência, tem apenas pouco mais de 100 anos de idade e permanece há anos-luz de outras ciências em termos de sofisticação. Não bastasse a demora para que os estudos científicos fossem iniciados, consumiu-se grande parte dos primeiros anos afastando-se os conceitos errôneos que parecem surgir naturalmente, toda vez que as pessoas se envolvem em empreendimento controvertido, como é o caso do estudo científico da mente.

O quadro estático do estudo da psicologia começou a mudar quando Charles 
Darwin, na década de 50 do século XIX, sugeriu que as características mentais apresentam continuidade entre as espécies, assim como acontece com qualquer outra característica estrutural. Se os membros dianteiros, por exemplo, apresentam o mesmo padrão geral em todos os animais, sejam mamíferos, pássaros ou répteis, de tal forma que se pode traçar uma linha evolutiva entre eles, deve-se utilizar a mesma lógica para estudar os processos mentais, como pensamento, linguagem e memória.

Logo depois de Darwin ter publicado A origem das espécies, o psicólogo alemão Hermann Ebbinghaus conseguiu levar o estudo da memória para os laboratórios. Larry Squire e Eric Kandel (2003) narram que, com o intuito de estudar a memória de forma objetiva e quantitativa, Ebbinghaus inventou um tipo de sílaba, na qual o som de uma vogal era colocado entre duas consoantes, como DAX, BUP ou REN. Ele construiu cerca de 2.300 dessas sílabas, escreveu cada uma delas num pedaço de papel, misturou-as e retirou-as ao acaso para formar listas para seu experimento. Decorou listas de 13 sílabas a ponto de ser capaz de repeti-las duas vezes, em ordem e sem erro. Depois, testou sua capacidade de retenção dessas listas após variados intervalos. Ele registrava o tempo que levava para reaprendêlas, adotando o mesmo critério de duas repetições sem erro.

Assim, Ebbinghaus foi capaz de descobrir dois princípios sobre o armazenamento da memória. Primeiro, demonstrou que as memórias têm diferentes tempos de duração. Algumas duram pouco, enquanto outras persistem por dias ou meses. Segundo, provou que a repetição faz com que as memórias durem por períodos mais longos.

Posteriormente, o filósofo e psicólogo americano William James desenvolveu esses achados e fez distinção qualitativa clara entre memórias de curta e de longa duração. James argumentou que as memórias de curta duração duram de segundos a minutos e são, essencialmente, extensão do tempo presente. (apud Squire \& Kandel, 2003) Ao contrário, a memória de longa duração pode resistir durante dias, semanas ou toda uma vida, e seu acesso é possível somente com consulta ao tempo passado. Essa distinção mostrar-se-ia fundamental para a compreensão da memória.

No início do século XX, inspirados pelos estudos de Ebbinghaus e pelas idéias evolucionistas de Charles Darwin, o russo Ivan Pavlov e o americano Edward Thorndike, ambos excepcionais psicólogos, começaram a desenvolver modelos de estudo em animais para a compreensão do aprendizado. Trabalhando independentemente e separados por milhares de quilômetros, cada um deles descobriu um conceito diferente na modificação do comportamento. Pavlov desenvolveu o condicionamento clássico, enquanto Thorndike descobriu o condicionamento operante; ambos passaram a constituir a base para o estudo e a compreensão do aprendizado e da memória em animais. No condicionamento clássico, o animal aprende 
a associar dois estímulos, um incondicionado e outro neutro, de tal forma que passe a comportar-se diante do estímulo neutro tal qual faria diante do estímulo incondicionado. Já no condicionamento operante, o animal aprende a fazer associação entre uma resposta e uma recompensa ou uma punição, de tal forma que haja mais respostas que levem a recompensas e menos que resultem em punição. (Catania, 1999)

Os estudos de Pavlov e Thorndike estão na base da tradição empírica denominada behaviorismo, que fez enorme sucesso, especialmente nos Estados Unidos, onde foram liderados por John B. Watson. Os behavioristas argumentam que o comportamento pode ser estudado com o mesmo rigor científico empregado em outras ciências, mas, para tanto, o psicólogo deve-se concentrar exclusivamente no comportamento observável.

Esse método estrito logo se mostrou restritivo, e questões de grande importância para a psicologia foram relegadas a segundo plano por serem consideradas anticientíficas. Os behavioristas definiram a vida mental nos termos da técnica de observação limitada e restringiram os domínios da psicologia experimental a um conjunto exíguo de problemas, excluindo dos estudos algumas das mais fascinantes características do ser humano, tais como, os processos cognitivos que ocorrem quando aprendemos e lembramos alguma coisa. $\mathrm{O}$ behaviorismo ignorou, e ignora, que os processos mentais que intervêm nessas situações constituem os fundamentos da percepção, da atenção, da motivação, da ação, do planejamento e do pensamento, além do aprendizado e da memória.

Durante a primeira metade do século XX, a psicologia foi quase totalmente dominada pelo programa behaviorista. Mas, a partir da década de 50, a evolução em outras áreas de conhecimento - Anderson (2003) cita a informática, a lingüística, a genética e a teoria dos sistemas - lançaram dúvidas sobre a validade da ortodoxia behaviorista no estudo dos processos mentais.

No que tange ao estudo da memória, um dos primeiros a dar-lhe enfoque menos comportamental e mais cognitivista foi o psicólogo britânico Frederic Barlett. Em meados do século passado, Barlett estudou a memória em ambientes naturais, fazendo as pessoas aprenderem pelo uso de material cotidiano, como fotografias e histórias. Em seus estudos, Barlett foi capaz de demonstrar que a evocação não é simplesmente reprodução automática de informação previamente armazenada, como queriam os comportamentalistas. Ao contrário, segundo ele, a evocação é essencialmente um processo criativo de reprodução. Na década de 60 , os limites estreitos do behaviorismo ficaram evidentes para muitos psicólogos. A partir das conclusões de Barlett, começou-se a considerar que a percepção e a memória não dependem apenas das informações fornecidas pelo ambiente mas também da estrutura mental do observador e daquele que evoca. 
Essa nova visão da psicologia, que viria a ser conhecida como a "revolução cognitiva", culminou com a publicação de Cognitive Psychology, de Ulric Neisser, em 1967, obra que deu a definitiva legitimidade ao campo da psicologia cognitiva. Nela, Neisser analisa cognitivamente a percepção, a atenção, a linguagem, a memória e o pensamento. A tarefa não se limita, tacanhamente, a analisar os estímulos e as respostas que produzem, mas considera os processos que intervêm entre o estímulo e o comportamento. Nasce o cognitivismo. A psicologia respira.

\section{Aquisição, armazenamento, recuperação}

Como a psicologia cognitiva estuda a memória? Conforme ressaltam Gleitman, Fridlund e Reisberg (2003), primeiro é preciso ter em mente que a memória não é entidade unificada. O termo memória refere-se a grande número de processos cuja função precípua é criar uma ponte que ligue o passado ao presente. Como os processos para memorização são diferentes, pode-se afirmar que não há memória, mas memórias.

Alguns processos, no entanto, são comuns a todos os tipos de memória. Qualquer ato de lembrar implica que houve sucesso em três aspectos. Primeiro, para lembrar, é preciso que haja algo a ser lembrado. Lembra-se agora de um dado que foi apreendido no passado. Isso pode parecer óbvio, mas muitos problemas de memória são, de fato, um problema nesse primeiro processo, chamado de aquisição. Para que o dado seja propriamente adquirido, é necessário que coexistam dois fatores primordiais: percepção e atenção. Qualquer falha nos sentidos ou no sistema de atenção pode ser determinante para que a aquisição não ocorra, impedindo as informações de serem apreendidas e, conseqüentemente, memorizadas.

O segundo processo é o armazenamento. Para que seja lembrada depois, uma experiência deve deixar alguma gravação - um traço de memória - no sistema nervoso. Uma questão a ser levantada é como o conteúdo da memória é gravado no tecido cerebral. Citando o exemplo de Squire e Kandel (2003), como o trabalho dos neurônios permite que você se lembre do que comeu no almoço? Outra questão importante é onde, no cérebro, as memórias são gravadas. As evidências sugerem que os dados individuais de memória não são guardados em lugar específico, mas distribuídos em várias seções do tecido cerebral. A localização do traço de memória é, aliás, uma das principais características diferenciadoras dos vários tipos de memória.

A última fase do ato de lembrar é a recuperação, o ponto no qual a informação é retirada de seu lugar de armazenamento e tornada disponível para uso. Gleitman et al. distinguem a recuperação em relembrar e reconhecer. Tentar lembrar as respostas para perguntas como "a que filme você assistiu ontem no cinema?" ou "quem 
descobriu o Brasil?" seriam formas de relembrar. Já respostas para perguntas, tais quais, "o filme a que você assistiu ontem chama-se Amnésia?" ou "é este o homem que você viu na noite do crime?", referem-se ao ato de reconhecer.

\section{Teoria da memória por estágios: memórias de curto e de longo prazo}

De acordo com Gleitman et al., a imagem da memória como um grande armazém remonta aos antigos gregos, que comparavam as memórias a objetos colocados em compartimentos, de onde poderiam ser retirados quando fosse necessário. Em tempos modernos, a imagem mais utilizada é a de um disco-rígido de computador, onde os dados são salvos e lá permanecem até que deles se precise, ocasião em que são acessados e utilizados.

A teoria da memória por estágios, desenvolvida nos anos 1960, apóia-se nesse conceito. O ponto central é que os dados são armazenados não apenas em um, mas em vários compartimentos, por meio dos quais se movimenta em estágios. (Gleitman et. ali, op. cit.) Segundo o psicólogo cognitivo John Anderson (2004), o nascimento dessa teoria marcou o poder da nova metodologia cognitiva em tratar um grande volume de dados de maneira que não havia sido possível com as anteriores teorias behavioristas. Ainda de acordo com Anderson, a teoria da memória por estágios propõe que as informações aprendidas vão para uma memória de curto prazo intermediária, na qual têm de ser repetidas para que possam passar para o estágio de memória permanente de longo prazo.

Mas, por que precisaríamos de dois tipos diferentes de memória? Para responder a essa questão, Gleitman, Fridlund e Reisberg propõem que se imagine a relação existente entre a mesa de trabalho de um estudante e as estantes cheias de livros de uma biblioteca. As estantes contêm mais livros (informações), mas são de acesso mais difícil. Ao fazer um trabalho escolar, o estudante, provavelmente, dirige-se à biblioteca, escolhe os livros necessários e leva-os para cima de sua mesa, pois isso torna o acesso às informações muitíssimo menos dispendioso, além de mais rápido. A mesa, porém, é evidentemente menor que a biblioteca, logo poucas informações ficam disponíveis ao mesmo tempo.

A teoria da memória por estágios propõe arquitetura similar. Quando se quer guardar, por longo tempo, grande número de informações das quais não se precisará imediatamente, utiliza-se a memória de longo prazo. Se o intuito, porém, for reter número menor de informações por pouco tempo, com as quais se trabalhará agora, o lugar ideal para isso é a memória de curto prazo, não por acaso conhecida como memória de trabalho. 
Um ponto importante da teoria é que, antes de serem guardados na memória de longo prazo, os dados, necessariamente, devem passar pela memória de trabalho. Vista desse modo, a memória de trabalho funciona como pequena plataforma de lançamento, situada bem em frente ao grande armazém da memória de longo prazo.

Para que as informações migrem da memória de trabalho para a de longo prazo, devem ser insistentemente acessadas, ou seja, repetidas. Qualquer um que já tentou decorar rapidamente um número de telefone ou uma lista de palavras sabe que o melhor método para isso é repetir os dados até que se fixem na memória. Mas, se a lista ou o número a ser decorado for longo, algo interessante acontece. Começa a surgir um padrão entre quais números ou palavras serão ou não lembrados: dados que aparecem no começo da lista são mais prováveis de serem decorados; é o chamado efeito de primazia. O mesmo acontece com os dados do final da lista; isso é conhecido como efeito de recência.

\section{Uma mudança de foco: memória ativa e organização}

A teoria dos estágios dominou os estudos sobre memória durante vários anos. As evidências mostravam que a arquitetura da memória havia sido descrita de forma satisfatória. Mas, logo se percebeu que a teoria não havia levado em conta uma variável crucial: a importância do papel desempenhado pelo sujeito que memoriza suas estratégias e seus objetivos, e, acima de tudo, o conhecimento prévio que as pessoas já trazem consigo sempre que memorizam alguma coisa.

Os pesquisadores perceberam a falha quando experimentos começaram a mostrar que a repetição não era suficiente para que os dados migrassem da memória de trabalho para a memória de longo prazo. A visão da memória de trabalho como receptáculo passivo, à espera de repetição, estava errada. Ao contrário, a memória é processo ativo, em que a organização mental, as atitudes e os desejos da pessoa que memoriza desempenham papel central na transferência da memória de trabalho para a de longo prazo.

Dizer que a memória é processo ativo implica afirmar que existem variáveis que influenciam na qualidade da memorização. A primeira delas refere-se à profundidade do processamento. Para entender isso, é necessário introduzir outro conceito importante no estudo da memória: a codificação. A aquisição de memória não é questão de "copiar" um dado ou evento e inseri-lo no cérebro, como se os humanos fossem máquinas fotográficas. Memorizar requer atenção e envolvimento intelectual para com aquilo que se deseja aprender, pois, como salienta Anderson, não é o fenômeno que será memorizado, mas aquilo que se pensa dele durante o processo de memorização. Em outras palavras, a memória requer que os dados 
brutos do ambiente sejam traduzidos em linguagem intelectual memorizável. Esse processo de tradução é chamado de codificação.

De acordo com Gleitman e outros, o processamento superficial é aquele cuja codificação enfatiza características superficiais de um estímulo. O processamento profundo, ao contrário, é focado no significado dos dados memorizáveis. Experimentos mostram que atribuir significado a informações ou eventos faz com que sejam mais facilmente recordados no futuro.

Na vida diária, isso é facilmente verificável. Pergunte a alguém onde ele estava no dia primeiro de maio de 1994. Dito assim, dificilmente, alguém vai lembrar-se. Mas, uma vez que se informe que foi nesta data que morreu Ayrton Senna, provavelmente, todos que tiverem idade para isso se lembrarão. Da mesma forma, quem presenciou os acontecimentos de 11 de setembro de 2001 quase certamente jamais esquecerá o que fazia quando soube da destruição das Torres Gêmeas de Nova Iorque.

\section{Memória explícita}

Além do par memória de curta duração-memória de longa duração, existe outro binômio sob o qual os estudiosos costumam classificar a memória: a explícita e a implícita. Se o primeiro par foi forjado com base na variável tempo em que a memória é retida, a dicotomia explícita versus implícita foi construída sobre os fundamentos de outro antigo problema para a psicologia: consciência versus inconsciência. Segundo essa classificação, a memória explícita é consciente, enquanto a implícita ocorre inconscientemente.

O problema da consciência é complexo o bastante para merecer estudo independente. Para fins deste trabalho, aceitaremos que o caráter consciente da memória explícita refere-se à sua capacidade de ser acessível à linguagem verbal, de poder ser declarada por aquele que memoriza. Assim, a memória explícita, ou declarativa, é o tipo a que as pessoas se referem quando falam em trazer à mente um evento passado, seja a lembrança de amigo ausente ou pensamento passageiro sobre um evento ocorrido em suas vidas. Essas recordações têm, em comum, o fato de serem conscientes, de poderem ser relatadas, de permitirem relato verbal, no presente, de algo que aconteceu no passado.

A memória explícita é, portanto, para eventos, fatos, palavras, faces, música e todo e qualquer fragmento do conhecimento que se adquire durante a vida, que pode ser declarado na forma verbal ou como imagem mental. William James já se havia referido a esse tipo de memória como estado de conhecimento prévio da mente, após já não estar sendo mantido na consciência, ou, então, continua ele, o 
conhecimento de um evento ou fato sobre o qual não se esteve pensando, mas com a consciência de que se já pensou sobre ele ou vivenciou-o anteriormente. (apud Squire \& Kandel, 2003)

Como ressaltam Squire e Kandel (op. cit.), é preciso ter em mente que a memória explícita não opera independentemente dos outros tipos de memória, pois sabese que o mesmo evento pode dar origem a diversos tipos de memórias. Os autores dão o exemplo de uma pessoa que, por acaso, encontra um cão na rua. Mais tarde, pode recordar o encontro conscientemente e relatá-lo a alguém. Mas, essa mesma pessoa pode, por exemplo, desenvolver afeto ou fobia por esse cão, ou identificar, em segundo encontro, que o cão está mancando, o que não ocorria no primeiro encontro. Esses últimos efeitos são casos de memória implícita, discutido adiante.

\section{Memória episódica}

Em 1972, o psicólogo Endel Tulving propôs que havia, no sistema de memória explícita, um subsistema, um subtipo de memória, ao qual deu o nome de memória episódica. (apud Tulving, 2002) Segundo ele, essa distinção faz-se necessária, pois parece haver duas fontes básicas para a memória explícita: uma diz respeito aos fatos em geral, e a outra se refere a fatos específicos ocorridos na vida de alguém. A memória episódica é, portanto, a autobiográfica de um indivíduo.

Memória episódica é o "tipo de memória que possibilita uma recuperação consciente dos acontecimentos e eventos ocorridos no passado da pessoa que os recorda, permitindo, assim, uma projeção mental de antecipação dos eventos de um futuro subjetivo". (Wheeler, Stuss \& Tulving, 1997, p. 331) Por essa definição, a memória episódica refere-se a acontecimentos ocorridos em lugar particular, em data específica. É a memória episódica que armazena marcos espaciais e temporais que identificam quando e onde um evento ocorreu.

De acordo com Tulving (2002), a memória episódica é orientada para o passado de forma muito mais profunda que os outros tipos de memória. É o único sistema que permite às pessoas reexperimentar o passado, o que faz dela a principal responsável pela capacidade que o ser humano tem de "viajar no tempo". Por essa especificidade complexa, acredita-se que o sistema de memória episódica evoluiu no ser humano apenas recentemente. As recentes descobertas entre as relações da memória episódica com os lobos temporais parecem confirmar essa hipótese.

\section{Memória implícita}

Ao lado do conhecimento passível de descrição, existe um grande número de informações que são adquiridas sem que se tenha consciência delas. Um pianista 
experiente toca seu instrumento sem precisar pensar na disposição das notas no teclado. $\mathrm{O}$ mesmo acontece com outros instrumentos musicais ou com o teclado de uma máquina de escrever. $\mathrm{O}$ instrumentista ou o datilógrafo não precisam conscientemente lembrar-se do que aprenderam para realizar tocar ou datilografar. Esses são exemplos típicos de memória não declarada, ou implícita. O que chama a atenção é que há dissociação entre o conhecimento verbalizável e o não verbalizável. Se pedirmos para um datilógrafo dizer, de memória, a localização exata das teclas da máquina, muito provavelmente, terá dificuldades. A memória explícita, nesse caso, é falha, enquanto a memória implícita é total.

Ao contrário da memória explícita, a implícita é inconsciente - não acessável pela verbalização - e isso cria uma série de distinções entre esses dois tipos de memória. Em primeiro lugar, a memória implícita pode ser criada por fatos dos quais o sujeito não se lembra, como ocorre no caso de estímulos subliminares que podem levar as pessoas a comportarem-se de determinada maneira sem que saibam exatamente por quê.

Além disso, memórias explícitas e implícitas parecem funcionar de modo diferente. Foi visto que a performance em memória explícita é aumentada quando os sujeitos prestam atenção ao significado das informações; isso parece não ocorrer na memória implícita, pois, de acordo com Gleitman et al. (op. cit.), estudos mostram que testes de memória implícita apresentam resultados similares, independentemente do nível de codificação utilizado na aquisição. Os mesmos autores sugerem que as memórias implícitas são automáticas e não sujeitas a controle. Isso significa que influenciam o comportamento e os julgamentos independentemente da vontade daqueles que as possuem.

\section{Quando a memória falha}

No uso popular, a palavra esquecer é empregada sempre que ocorre falha de memória. Mas, as falhas de memória têm muitas causas e, por isso, não podem ser rotuladas sob a mesma palavra. Algumas falhas estão relacionadas com a codificação; outras surgem quando há aquisição ineficiente; outras, ainda, aparecem no momento da recuperação. Gleitman, Fridlund e Reisberg (op. cit.) afirmam que as falhas de memória devem sempre ser analisadas levando-se em conta dois aspectos: a passagem do tempo, que faz com as informações sejam mais probabilisticamente esquecidas, e os erros de memória propriamente ditos, aqueles em que as pessoas se lembram do passado de forma diferente do que realmente aconteceu.

Desde Ebbinghaus, ficou cientificamente provado o que todos já sabiam: a passagem do tempo tem grande influência sobre a memória. Quanto maior o intervalo de tempo entre a memorização e a recuperação das informações, menor a 
probabilidade de serem recuperadas. Segundo a teoria mais aceita, isso acontece porque os traços de memória apagam-se com o tempo, tal qual as montanhas são desgastadas pela água e pelo vento. Segundo Gleitman et al. (op. cit.), essa "erosão" de memórias é presumivelmente causada pelos processos metabólicos normais que deterioram os traços de memória, até apagá-los por completo.

Outra teoria supõe que os traços de memória não são nem danificados nem apagados, mas mudados de lugar por interferência de novas memórias que são continuamente adquiridas. Os autores da teoria costumam usar analogia simples. Considere-se uma pessoa que compra os jornais todos os dias e, dia após dia, coloca-os na mesma pilha, no mesmo lugar. No começo, é fácil encontrar qualquer exemplar, mas, com o passar do tempo, encontrar um jornal específico pode-se tornar quase impossível.

Essa teoria induz a pensar que, quanto mais se aprende, menos se lembra. $\mathrm{O}$ impasse é resolvido levando-se em conta que a interferência de novo material não é indiscriminada, mas específica para materiais similares. Aprender a andar de bicicleta não faz com que se esqueçam os verbos irregulares em inglês. Além disso, as informações novas não vão interferir nas informações antigas se houver compatibilidade entre elas; ao contrário, a aprendizagem subseqüiente de informações pode ajudar a memória e, não, destruí-la.

Casos em que as informações parecem estar inacessíveis por terem mudado de lugar compõem o tipo mais comum de erro de memória. Isso constitue um problema na recuperação, uma vez que os dados foram perfeitamente codificados, adquiridos e armazenados. A prova de que as memórias não foram danificadas é que uma "dica" pode fazer com que as pessoas lembrem-se de pronto daquilo que parecia estar esquecido para sempre.

O exemplo clássico de problemas na recuperação é a chamada amnésia infantil, ou seja, o fato de os adultos não serem capazes de lembrar-se dos fatos ocorridos quando eram crianças. Gleitman, Fridlund e Reisberg apontam dois motivos para a amnésia infantil. O primeiro é que o adulto vê o mundo de perspectiva muitíssimo diferente da criança, o que dificulta o acesso às memórias. O segundo motivo seria que o hipocampo e o córtex pré-frontal, que desempenham importantes tarefas na memorização, não estão plenamente amadurecidos até que a pessoa tenha 4 ou 5 anos de idade.

Para o neurocientista Iván Izquierdo, há duas formas de esquecimento que implicam tornar as memórias menos acessíveis, mas sem que se as perca por completo: a extinção e a repressão. A extinção é a diminuição gradativa de uma resposta condicionada a estímulo neutro; já a repressão consiste na dificuldade inconscientemente criada para acessar-se as memórias cuja evocação resulta desagradável. 
Existe um outro tipo de transtorno da memória que não está ligado à codificação, nem à aquisição ou à evocação. São os defeitos causados por de danos cerebrais cujo principal efeito sobre a memória é a amnésia, que pode apresentar-se de duas formas: anterógrada ou retrógrada.

Certas lesões no córtex temporal produzem amnésia cuja principal característica é a impossibilidade de formação de novas memórias. Essa é a chamada amnésia anterógrada, causada principalmente por derrame cerebral e traumatismo craniano. Uma das principais causas, no entanto, é um tipo específico de desnutrição causada por alcoolismo crônico; nesse caso, a amnésia anterógrada surge como um dos sintomas de uma doença chamada Síndrome de Korsakoff.

A amnésia retrógrada, por seu turno, é aquela na qual o paciente sofre perda da memória dos períodos anteriores ao trauma. Uma pancada não muito forte na cabeça pode resultar em pequena amnésia retrógrada; já o esquecimento de períodos longos, como semanas, meses e anos, pode ser conseqüência de tumor no cérebro, traumatismo craniano ou derrame cerebral. É importante ressaltar que os dois tipos de amnésia não são auto-excludentes, ou seja, podem ocorrer separadamente ou ao mesmo tempo.

\section{Da mente ao corpo}

\section{O problema mente-corpo: muito além de Descartes}

Em 1644, o pensador francês René Descartes lançou a obra Princípios de Filosofia. Ali, escreveu a frase que se tornaria a mais citada de toda a história da filosofia: "Penso, logo existo", ou, no original em latim, "Cogito, ergo sum". (Apud Damásio, 1996, p. 279)

Embora tenha sido Platão o primeiro filósofo a propôr que havia duas instâncias na psique humana, é o nome de Descartes que está definitivamente associado a essa tradição. (Durant, op. cit.) O cartesianismo teve, e ainda tem, impacto sobre a humanidade. Não por acaso, Descartes é por muitos considerado, conforme Padovani e Castagnola (op. cit.), o fundador da moderna filosofia, o que significa dizer que é um dos fundadores da modernidade. Sua frase famosa espelha bem seu pensamento. Para ele, o homem é composto de duas instâncias, distintas e separadas uma da outra: uma física, o corpo, e outra metafísica, a mente. À mente pensante chamou res cogitans; ao corpo não pensante, res extensa. A esse tipo de visão de homem dá-se o nome de dualismo.

O sucesso da visão dualista é facilmente constatável no dia-a-dia. Todos aqueles que acreditam em alma ou espírito, por exemplo - e não são poucos - são cartesianos, embora muitos possam não saber disso. 
Não obstante seu sucesso, o dualismo cartesiano sofreu duras críticas de outros pensadores. Muitos acham que a crença na alma é ultrapassada e pouco científica. Tudo o que existe no mundo é feito de matéria física - diferentes combinações dos elementos químicos. Por que não seria assim com os seres humanos também? Mediante complexo processo físico, o corpo humano desenvolve-se a partir de célula única, produzida pela união do espermatozóide com o óvulo, no momento da concepção. Aos poucos, matéria comum é adicionada, de tal forma que a célula se torne uma pessoa, com braços, pernas, olhos, orelhas e cérebro, capaz de mover-se, sentir, ver e, finalmente, falar e pensar. Alguns acreditam que esse sofisticado sistema físico é suficiente, por si só, para fazer surgir a vida mental. Por que não deveria? Como um simples argumento filosófico pode demonstrar que não é assim? Como questiona Nagel (2004), se os filósofos não são capazes de dizer de que são feitos as estrelas e os diamantes, como poderiam saber de que são feitos os seres humanos?

A opinião de que as pessoas não passam de matéria física e de que seus estados de espírito são estados físicos cerebrais é denominada fisicalismo ou materialismo. O mesmo Nagel (id. ibid.) salienta que, embora os fisicalistas não tenham teoria específica sobre de que forma os processos cerebrais ligam-se às experiências pessoais, acreditam que os chamados estados de espírito são estados químicos do cérebro.

De todas as explicações materialistas, a que mais influenciou a psicologia foi o behaviorismo radical. Segundo essa visão, "os processos conscientes e os processos mentais não existem: a sua existência pode ser repudiada". (Popper \& Eccles, 1995, p. 78) Para usar os termos do eminente behaviorista, John Watson, “palavras como 'mente' e 'consciência' são desprovidas de significado". (apud Schultz, 1985, p. 189)

Há outra visão que se difere tanto do dualismo cartesiano quanto do materialismo de acordo com a qual a vida mental ocorre no cérebro, ainda que experiências, sentimentos, pensamentos e desejos não sejam processos físicos do cérebro. Isso significa que a massa cinzenta dos 100 bilhões de neurônios não é apenas um objeto físico, pois, embora tenha muitas propriedades físicas, ali também ocorrem processos mentais.

A concepção de que o cérebro é a sede da consciência, mas que seus estados conscientes não são meros estados físicos, é chamada de "dualismo de propriedades". (Teixeira, 2000, p. 89) Os dois principais teóricos desse tipo de pensamento são David Chalmers e o já citado Thomas Nagel. Segundo Teixeira, o filósofo australiano David Chalmers sustenta que a consciência e a experiência subjetiva devem ser tomadas como elementos básicos ou fundamentais de qualquer teoria da mente; essas devem ser ponto de partida e não de chegada por não serem passíveis de 
redução ou explicação em termos de entidades mais simples derivadas da neurociência ou da física. Ao classificar a consciência como entidade básica do mundo - como átomos ou partículas atômicas - Chalmers naturaliza a mente, e, por isso, sua concepção é conhecida como "dualismo naturalista".

O outro grande defensor moderno do dualismo de propriedades é o norteamericano Thomas Nagel, que expôs sua teoria em dois artigos célebres, Physicalism (1965) e What is it like to be a bat? (1974). Nesses artigos, argumenta que existem estados mentais que, por suas propriedades específicas, não podem ser descritos a partir de um vocabulário materialista, pois vocabulário e linguagem são intersubjetivos e autoreferentes, ou seja, a linguagem só se refere e descreve os estados mentais, mas não permite vivência de tais estados, o que seria necessário para sua total compreensão; some-se a isso que o ponto de vista subjetivo é único e irredutível à linguagem, ou seja, a linguagem não o atinge e nada se assemelha a ele. Nagel deu à sua teoria o nome "teoria do aspecto dual", assim chamada por defender que, quando um ser humano entra em contato com um estímulo, produzse, no cérebro, um estado ou processo com dois aspectos: um físico, envolvendo as várias alterações químicas e elétricas, e um mental, qual seja a experiência subjetiva do indivíduo perante aquele determinado estímulo. (Nagel, 2004, p. 32)

Tanto o dualismo cartesiano quanto o fisicalismo não deram à ciência condições para investigar os processos mentais. Este porque os nega, aquele porque os torna metafísicos, para além da compreensão científica. Foi somente com a adoção de um ponto de vista que se assemelha ao que Chalmers e Nagel postulam que as ciências cognitivas, incluídas psicologia, neurociência e teoria da informação, conseguiram atingir o nível de progresso e excelência verificados no final do século $\mathrm{XX}$.

\section{A neurociência cognitiva como uma ponte entre o corpo e a mente}

Apesar das tentativas, chega-se ao século XXI sem que a filosofia e outras ciências sociais, como antropologia, sociologia e direito, tivessem sido capazes de transpor o abismo construído para definir o ser humano, que separa a matéria da mente, o material do espiritual, o físico do mental, a biologia da cultura. (Pinker, 2004) No entanto, novas fronteiras do conhecimento, como o estudo científico da mente, do cérebro, dos genes e da evolução, consegue o que parecia impossível: ligar os dois lados do abismo, criando nova compreensão da natureza humana.

Nesse quadro, surge como a principal responsável por essa nova compreensão de homem a neurociência cognitiva, que pode ser definida como o estudo de como 
a cognição e a emoção são implementadas no cérebro e, por isso, mesmo se constitui, ainda segundo Pinker, em uma ponte entre o cérebro e a mente. Conforme salienta Kandel et al. (2003), o principal objetivo da neurociência cognitiva é estudar as representações neurais dos atos mentais, ou seja, busca descobrir a representação interna, passada no encéfalo, de cada ato motor ou de percepção emitida por um indivíduo.

Em outras palavras, a pergunta à qual a neurociência tenta responder é "qual é o conteúdo de informação do cérebro?”. (Sagan, 1985, p. 15) Na busca para responder a essa pergunta, a neurociência foi composta, ao longo de sua história, de acordo com cinco grande abordagens, conforme relatado por Kandel et al. (op. cit.).

Primeiramente buscou-se a correlação entre células individuais específicas e determinados comportamentos. Esses estudos foram realizados, principalmente, nas décadas de 60 e 70 do último século, por meio da observação da atividade individual dos neurônios no encéfalo de animais não anestesiados e sem restrição física que podiam, assim, expressar quaisquer comportamentos. Logo depois, vieram os estudos celulares em macacos, que tornaram possível correlacionar padrões de disparo em células individuais, em regiões específicas do encéfalo, com processos cognitivos superiores, como atenção e tomada de decisão. Em terceiro lugar, a neurociência valeu-se do estudo em pacientes com lesões encefálicas que interferem no comportamento. Em quarto lugar, novas técnicas de imagem radiológica, como a tomografia por emissão de prótons (PET, na sigla em inglês), e a tomografia por ressonância magnética (MRI), também deram grande impulso à neurociência. E, finalmente, outra grande fonte de contribuição veio da ciência computacional, que tornou possível a modelagem da atividade de grandes populações neuronais.

Todas essas fontes permitiram à neurociência, primeiramente, falsear a chamada teoria da equipotência cerebral, segundo a qual, qualquer parte do cérebro pode ser substituída por outra, uma vez que não há localização de funções. Hoje, no entanto, está provado que as funções cognitivas específicas localizam-se em locais determinados do cérebro. Pesquisas com a memória de pacientes que sofreram lesão cerebral, como as realizadas por Milner ou as feitas por Lashey (id. Ibid.) foram fundamentais para provar que havia, no encéfalo, locais específicos para funções específicas. (Squire \& Kandel, 2003) Porém, foram os trabalhos do neurocirurgião canadense Wilder Penfield que confirmaram definitivamente a teoria. (Sagan, op. cit.)

Na tentativa de aliviar os sintomas de certas doenças, como a epilepsia, Penfield estimulou eletricamente várias partes do córtex cerebral de seus pacientes. O resultado, surpreendente, foi que os pacientes, ao terem determinadas áreas do córtex estimuladas, relataram vislumbres de memória, como um cheiro sentido na 
infância, ou sons e cores que pareciam provir diretamente do passado deles. Como os pacientes normalmente se encontravam conscientes durante a estimulação, Penfield pôde descobrir que, se dissesse ao paciente que estava estimulando seu cérebro, quando, na verdade, não estava, invariavelmente, o paciente não relatava qualquer vestígio de memória. Mas, quando, sem o paciente notar, a corrente fluía pelo córtex, surgiam ou permaneciam traços de memória. Após essa descoberta, Penfield voltou suas pesquisas para o córtex sensorial, e é dele uma figura onipresente em livros de neurociência, o homúnculo motor.

Além de desmontar o conceito de equipotência cerebral, a neurociência conseguiu abalar outra antiga idéia sobre a natureza humana, a de que cada um de nós possui usuário interno - o self, a alma, o fantasma, a pessoa, o eu. Pinker (2004), categoricamente, afirma que a neurociência cognitiva mostra o self ser, na verdade, o resultado de uma rede de sistemas cerebrais.

Casos como o de Phineas Gage - o célebre empregado de ferrovia do século XIX que, após acidente que lesionou seu cérebro, teve seus padrões comportamentais alterados - ajudaram a neurociência a demonstrar que o self unificado é ilusão. Uma das mais impressionantes demonstrações disso foi dada pelos neurocientistas Michael Gazzaniga e Roger Sperry. (Pinker, op. cit.) Seus estudos mostraram que, quando os cirurgiões cortam o corpo caloso que une os hemisférios cerebrais, cada hemisfério pode exercer o livre-arbítrio sem o conselho ou consentimento do outro.

A neurociência conseguiu provar que a geometria e as ligações cerebrais têm conseqüências reais para o pensamento, o sentimento e o comportamento. Pinker enumera descobertas recentes que correlacionam cérebro e mente: bebês que sofrem lesões em determinadas regiões cerebrais, freqüentemente, crescem com déficits permanentes em faculdades mentais específicas; nos gêmeos idênticos e fraternos, diferenças na quantidade de matéria cinzenta nos lobos frontais não são só geneticamente influenciadas mas também significativamente correlacionadas com diferenças no modo de pensar; um estudo do cérebro de Albert Einstein revelou que eram grandes e de formato incomum seus lobos parietais inferiores, que participam do raciocínio espacial e das intuições sobre números.

O estudo sobre a memória sofreu grande impulso quando foi assimilado pela neurociência a partir da década de 1950 . O que há muito era dito por psicólogos e filósofos sobre os aspectos mentais da memória, é colocado à prova pela neurociência. 


\section{Bases neurais da memória}

\section{Em busca do engrama}

Até a metade do século XX, a maior parte dos estudiosos do aprendizado não acreditava que as funções da memória estivessem localizadas em regiões específicas do cérebro. Segundo Kandel, Schwartz \& Jessell (2000), muitos cientistas chegaram a duvidar de que a memória fosse uma função distinta e específica do cérebro. Acreditavam, ao contrário, que a memória fosse uma parte da atenção, da linguagem ou da percepção e que estaria distribuída por todo o cérebro.

Essa opinião, no entanto, contrastava com os estudos realizados sobre outras funções superiores da mente, como a linguagem. Em 1861, o patologista francês Pierre Paul Broca evidenciou que lesões restritas à parte posterior do lobo frontal, no lado esquerdo do cérebro - região conhecida como área de Broca - produziam defeito específico na linguagem. Os já citados estudos de Penfield sobre representação motora igualmente contribuíram para que cada vez mais cientistas saíssem à busca da área ou das áreas cerebrais que fossem responsáveis pela memória. O que esses pioneiros buscavam era a representação física da memória, chamada de engrama.

Tudo o que é memorizado, como o significado de uma nova palavra, ou uma data histórica, ou um número de telefone, fica armazenado no cérebro. Mas onde? Onde estaria o engrama?

Uma das primeiras tentativas para se responder a essa pergunta foi feita pelo psicólogo americano Karl Lashley (1890-1958). Na década de 20 do último século, Lashley fez experimentos em ratos visando a encontrar a sede do engrama. Em experimento típico, um rato era colocado em um labirinto e media-se o tempo que levava para encontrar a saída. (Bear, Connors \& Paradiso, 2002) A cada tentativa, como era de esperar, o tempo para essa tarefa diminuía. Mas, Lashley percebeu que os ratos lesionados no cérebro tinham desempenho bem pior que aqueles sem lesões. Em uma variação, o rato era lesionado após ter sido treinado no labirinto, e, mais uma vez, verificou-se que a lesão interferia negativamente no seu desempenho.

Lashley, no entanto, inferiu que os déficits de memória se relacionavam com o tamanho da lesão, e não com sua localização, o que o levou a especular que todas as áreas do córtex estavam envolvidas na memória. De acordo com Bear et $a l$., a razão das inferências de Lashley, talvez, seja o tamanho das lesões, as quais eram tão grandes que danificavam várias áreas do cérebro.

Squire e Kandel ponderam, sobre os experimentos de Lashley, que a tarefa de aprendizado de labirinto empregada não era adequada ao estudo da memória, 
uma vez que dependia de diferentes capacidades sensoriais e motoras. Além disso, Lashley concentrou seus estudos apenas na camada externa do córtex, ignorando estruturas localizadas em nível mais profundo, as quais se revelaram, mais tarde, fundamentais para o entendimento da memória.

De todo modo, os trabalhos de Lashley foram importantes para eliminar possibilidades simples. Demonstrou, por exemplo, que não existe lugar único no cérebro onde todas as memórias sejam armazenadas permanentemente.

Um dos alunos de Lashley, Donald Hebb, em tentativa de explicar os resultados de seu professor, sugeriu que grupamentos de células, distribuídos em grandes áreas do encéfalo, trabalhem juntos na representação das informações. Embora a visão moderna seja a de que a memória esteja amplamente distribuída, mas com diferentes áreas armazenando diferentes aspectos do todo, os trabalhos de Hebb foram importantes por introduzir o conceito de redes neurais, um dos princípioschave do armazenamento de informações no encéfalo.

Mas, é inegável que vieram dos trabalhos de Penfield as primeiras evidências de que diferentes memórias estariam armazenadas em diferentes regiões do encéfalo. Encorajado pelos resultados de Penfield, outro neurocirurgião, William Scoville, obteve evidências diretas de que os lobos temporais são de importância central para a memória humana. Em 1957, conforme relatado por Squire e Kandel (op. cit.), Scoville, juntamente com sua colega, a psicóloga Brenda Milner, relatou a extraordinária história do paciente H.M. Começavam a serem desvendadas as bases neurais da memória explícita.

\section{Memória explícita}

H.M. sofreu um acidente de bicicleta aos nove anos, que lhe causou traumatismo craniano, o qual, mais tarde, levou ao desenvolvimento de epilepsia. As crises pioraram com o passar dos anos, e ele chegou a ter até 10 crises de ausência e crise convulsiva por semana. (Squire \& Kandel, op. cit.) Quando H.M. tinha 27 anos, seu médico, que vinha a ser William Scoville, decidiu, como último recurso de tratamento, pela retirada dos lobos temporais, pois, ali, Scoville julgava estar a fonte das crises de epilepsia de H.M. Conquanto a experiência tenha sido bem sucedida, H.M. passou a apresentar devastador déficit de memória, do qual nunca viria a recuperar-se. Desde a cirurgia, em 1953, até hoje, H.M. tem sido incapaz de converter nova memória de curta duração em uma de longa duração.

Brenda Milner descreveu esse déficit de atenção em artigo que se tornou o mais citado no campo das neurociências. Milner relatou quão notáveis eram - e ainda são - os problemas de memória de H.M. Ainda hoje, é incapaz de lembrar-se 
do que comeu minutos após ter tido uma refeição. Milner contou que, embora já se conhecessem há anos, toda vez que ela entrava no quarto ele era incapaz de reconhecê-la. Com o passar do tempo, ele tornou-se incapaz de reconhecer-se em fotografia, por não se lembrar das mudanças ocorridas em sua aparência. Os fatos em sua memória só são retidos enquanto sua atenção não se desviar deles.

Com base nesses estudos, Milner extraiu quatro princípios. Em primeiro lugar, a capacidade de adquirir novas memórias é uma função distinta de outras capacidades de percepção e cognição e está localizada na porção medial dos lobos temporais. Ou seja, o encéfalo separa suas funções intelectuais e de percepção da capacidade de armazenar os dados advindos dessas tarefas intelectuais e perceptórias.

Segundo, os lobos temporais não desempenham função na memória imediata, visto que H.M. possui esse tipo de memória perfeitamente intacto. Pode reter um número ou uma imagem por período curto, ou manter uma conversação curta com alguém.

Em terceiro lugar, Milner inferiu que os lobos temporais mediais e o hipocampo não são os destinos finais da memória de longa duração, visto que H.M. podia-se lembrar perfeitamente dos eventos de sua infância.

Finalmente, ela descobriu que havia um tipo de conhecimento que H.M. podia aprender e lembrar-se perfeitamente depois. Em experimento que se tornou clássico, ela ensinou-o a traçar o contorno de uma estrela de cinco pontas vista pelo espelho, habilidade na qual ele melhorava a cada dia. O interessante é que, a cada vez que recomeçava o desenho, H.M. declarava jamais ter feito aquela tarefa antes.

Essa última descoberta confirma o que já havia sido dito por Platão, Aristóteles, Bergson e William James. Todos eles afirmaram que havia, fundamentalmente, dois tipos de memória, uma que podia ser relatada e outra formada por hábitos. Milner havia apontado a localização exata da memória explícita.

Depois de Brenda Milner e seu caso famoso, muitos estudos foram feitos sobre as relações entre o lobo temporal medial e a memória declarativa. Segundo Bear et al. (op. cit.), hoje, sabe-se que há, no lobo temporal, um grupo de estruturas de grande importância para a memória explícita: o hipocampo, as áreas corticais próximas e as vias que conectam essas estruturas com outras partes do cérebro.

O hipocampo "é uma estrutura dobrada situada medialmente ao ventríloquo lateral" (id. ibid., p. 756). Ventralmente ao hipocampo, estão o córtex entorrinal, que ocupa a margem medial do sulco rinal, o córtex pré-rinal, na margem lateral, e o córtex pára-hipocampal, que se localiza, lateralmente (e posteriormente), ao sulco rinal.

Ainda segundo Bear e outros, os aferentes ao lobo temporal medial provêm de áreas associativas do córtex, contendo informações altamente processadas de 
todas as modalidades sensoriais. Isso quer dizer que as aferências trazem representações complexas, de grande importância para o comportamento, mas não informações simples, tais como, as diferenças entre o claro e o escuro. Os sinais atingem os córtices rinal e pára-rinal para, só então, serem passados ao hipocampo.

Mas, uma questão persiste: por que H.M. é capaz de ter memória de curtaduração, mas incapaz de armazenar dados por longo tempo? De acordo Squire e Kandel, a resposta parece estar na organização neural das funções de memória.

Embora os detalhes da passagem de memória de curto prazo para memória de longo prazo ainda não sejam perfeitamente conhecidos, Squire e Kandel ressaltam que o processo de fixação da memória explícita não se dá no momento do aprendizado, mas requer vários passos. A principal teoria vigente sustenta que o lobo temporal medial e suas estruturas são os responsáveis pelo armazenamento temporário dos dados perceptuais que, com o passar do tempo, migram dali para outras áreas corticais, transformando-se de memória de curta para de longa duração.

Para transformar uma percepção qualquer e sua memória imediata em memória declarativa persistente, os lobos temporais mediais do encéfalo primeiramente, armazenam aspectos da memória em desenvolvimento, e, só então, interagem com as áreas corticais responsáveis pelas bases da percepção e da memória imediata. Ainda segundo aqueles autores, a chave é que a lesão bilateral dos lobos temporais - como no caso H.M. - produz prejuízo grave e seletivo à memória declarativa, o transtorno clínico conhecido como amnésia.

Dada a lesão nos lobos temporais, o déficit é semelhante após remoção cirúrgica, traumatismo craniano, infarto, isquemia, anoxia ou qualquer outra doença. A razão pela qual os portadores de Alzheimer perdem, primeiramente, a capacidade de fazer memória de longo prazo é que a degeneração cerebral, nessa doença, inicia-se pelos lobos temporais.

Pode parecer tautologia, mas é importante realçar que a característica comum do déficit de memória é um grande esquecimento, sem distinção do tipo de informação que foi armazenada. Esquecem-se, igualmente, nomes, lugares, rostos, histórias, desenhos, relações de parentesco, odores ou sons. Além disso, estudos mostram que a intensidade da amnésia é diretamente proporcional ao tamanho da lesão. No caso de H.M., sua capacidade de adquirir memória explícita foi totalmente destruída, uma vez que a retirada do lobo temporal foi total. Mas, em pacientes com lesão menor, a amnésia é apenas parcial. Com frequiência, o principal defeito está na capacidade de adquirir novas memórias, mas memórias antigas também podem ser perdidas, inclusive as episódicas.

Desde o caso H.M., foi notável o avanço da neurociência no desvendamento da memória explícita, ainda mais se considerando que, por sua característica verbal, 
é praticamente impossível estudá-la em não humanos. Por isso mesmo, a definição exata da importância e do papel que cada um dos componentes do lobo temporal medial desempenha nesse processo ainda aguarda novas descobertas científicas.

\section{Memória episódica}

A memória episódica é um tipo especial de memória declarativa, responsável por armazenar os marcos temporal e espacial que identifiquem o tempo e o lugar em que um evento ocorreu. É, portanto, uma memória autobiográfica, é a "memória da fonte, isto é, a memória de quando e onde a informação foi adquirida". (Squire $\&$ Kandel, 2003, p. 120)

Até meados da década de 1980, a memória episódica era apenas uma teoria, sem nenhuma evidência material. Mas, estudos recentes demonstram o respaldo biológico da memória episódica, especialmente, por meio de pesquisas com sujeitos com danos cerebrais e também pela recente tecnologia de imagens do encéfalo. As pesquisas revelam que, ao lado da memória explícita armazenada nos lobos temporais, há outro sistema, que atua em conjunto com os lobos frontais: a memória episódica.

O caso mais pesquisado nesta área é o de K.C., um paciente estudado por Endel Tulving na Universidade de Toronto. (Tulving, 2002) A memória episódica de K.C. é totalmente disfuncional, e ele não tem consciência de si mesmo, embora estejam preservadas as outras funções intelectuais. Tulving relata que K.C. nasceu em 1951, e, quando tinha 30 anos, sofreu grave acidente de motocicleta que o deixou com lesões em várias regiões do cérebro, incluindo os lobos temporais mediais, o que lhe causou amnésia retrógrada, embora não muito grave. K.C. tem conhecimentos normais de fatos de história, gramática, geografia e matemática. Pode jogar xadrez, falar, andar de bicicleta. O que torna o caso dele especial é sua total amnésia sobre fatos ocorridos em sua vida. Como os lobos frontais foram muito danificados, inferese que esta lesão seja a responsável por sua amnésia autobiográfica.

Squire e Kandel (op. cit.) lembram que o papel desempenhado pelos lobos frontais no acesso a quando e onde os dados foram adquiridos estão bem delineados por duas evidências. A primeira é que pacientes com lesões nessa região do cérebro tendem a confundir onde e quando aprenderam aquilo que sabem. A segunda evidência é que erros na fonte da informação são comuns em crianças jovens e idosos, e sabe-se que os lobos frontais são lentos no amadurecimento, além de serem uma das primeiras regiões do cérebro afetadas pela senectude.

Tulving (op. cit.) escreve que os estudos com tomografia com emissão de pósitrons (TEP) são importantes para confirmar a teoria da memória episódica, pois 
demonstram que o ato de lembrar algum evento da própria vida está correlacionado com aumento da circulação de sangue no lobo temporal direito, o que não ocorre quando a lembrança se refere a dados simples da memória explícita. O envolvimento dos lobos frontais na memória episódica tem implicação profunda na natureza do aprendizado humano. Estudos com animais, como ratos, cães e macacos, mostram que eles podem lembrar-se de fatos passados, do contrário seriam incapazes de aprender alguma coisa. Porém, não está claro se têm marcação de quando e onde os dados foram apreendidos, como acontece conosco, os humanos.

Quando se pensa na organização cerebral, faz sentido imaginar que outros animais não têm essa consciência, pois os lobos frontais sofreram grande mudança na evolução recente dos humanos, tornando-se incomparavelmente maiores que os de qualquer outro animal, inclusive daqueles próximos a nós na cadeia evolutiva, como chimpanzés e bonobos. Por todas essas características especiais, a memória episódica parece ser uma das pistas a serem seguidas na resposta que há séculos acompanha a nossa espécie: o que nos faz humanos?

\section{Memória implícita}

Se as bases neurológicas da memória explícita são nebulosas, muito mais enigmáticas parecem ser as da memória implícita. Como já foi realçado, sob o conceito de memória implícita estão englobados vários tipos de memória, e, de acordo com Bear et al., estudos mostram que diferentes estruturas do encéfalo estão envolvidas em cada um desses tipos.

Kandel, Schwartz \& Jessell (2000) ressaltam que exemplos de memória implícita incluem as habilidades perceptivas e motoras, bem como o aprendizado de certos tipos de procedimento e regras, como as da gramática. Considera-se que a memória implícita para determinada tarefa envolva a atividade específica dos sistemas sensoriais e motores participantes do aprendizado da tarefa, a qual é conservada por mecanismos inerentes a cada um desses sistemas. Como resultado, a memória implícita pode ser estudada em sistemas reflexos simples, tanto em vertebrados como em invertebrados.

Sabe-se que a característica central da memória implícita é sua inconsciência verbal. Dessa forma, podemos inferir que sejam ativos em sua aquisição outros sistemas encefálicos que não os lobos mediais temporais, essenciais à memória explícita, eminentemente verbal. Alguns dos mais citados tipos de memória implícita são o priming, o aprendizado perceptual e o emocional, a memória para habilidades, os hábitos e o condicionamento.

Squire e Kandel definem priming como "um aperfeiçoamento da capacidade de detectar ou identificar palavra ou objetos após uma experiência recente com 
eles” (2003, p. 176). À primeira vista, isso pode parecer apenas um modo alternativo de falar da memória explícita. Entretanto, estudos mostram que o priming é um tipo diferente de memória. Em primeiro lugar, a principal característica do priming é ser inconsciente. Sua função é melhorar a percepção de estímulos encontrados recentemente, mas, em geral, essa melhora não é percebida conscientemente. Se um indivíduo desenhou uma estrela uma vez - para citar o experimento de Milner -, então torna-se mais rápido e eficiente a cada vez que realiza essa tarefa de novo.

Squire e Kandel (op. cit.) apresentam exemplos de experimentos sobre o priming, muitos deles realizados em pacientes com alto grau de déficit na memória explícita. Em um desses experimentos, os pesquisadores Stephen Hamann e Larry Squire apresentaram a um paciente com lesão no lobo temporal medial - portanto, com sérios problemas na memória declarativa - 24 palavras em inglês comum, as quais ele devia memorizar. Cinco minutos depois, apresentaram-no 48 palavras que apareciam na tela de um computador por cerca de 25 milissegundos. Dessas palavras, 24 eram novas, e 24 eram as que ele havia estudado. O paciente foi capaz de ler 55\% das palavras apresentadas anteriormente, mas apenas 33\% das palavras novas. Indivíduos que não apresentam problemas no lobo temporal têm desempenho idêntico.

Mas, se o priming é independente da memória explícita, onde, no cérebro, ocorre? Esta questão foi primeiramente abordada com a utilização do priming para completar raízes de palavras usando a técnica de tomografia por emissão de pósitrons (TEP). Nesse experimento, os sujeitos, inicialmente, estudavam uma lista de palavras, então eram-lhes dadas raízes de palavras com três letras, com a instrução de que completassem as raízes com a primeira palavra que lhe viessem à cabeça. A condição de priming verifica-se porque os sujeitos tendem a completar as raízes com as palavras anteriormente estudadas.

Outro tipo de aprendizado implícito é o perceptual, que se difere do priming por ser mais gradual, desenrolando-se ao longo de tentativas práticas. Kandel e Squire definem o aprendizado perceptual como uma capacidade de discriminar atributos perceptuais simples, como repetição do resultado dessa discriminação. Depois de várias tentativas, a pessoa torna-se um expert em discriminar determinado estímulo.

Esse tipo de aprendizado é mais estudado em sua relação com a visão humana. Com a prática, as pessoas podem melhorar a capacidade de discriminar texturas, direção de movimento, orientação das linhas e outros atributos visuais simples, indistinguíveis à primeira vista. Estudos com o aprendizado visual sugerem que ocorre em estágios iniciais de processamento sensorial no córtex visual, onde neurônios podem apresentar um crescimento de axônios, tornando-os maiores e mais ramificados, aumentando, assim, tanto a intensidade quanto o número das conexões sinápticas. 
Outra forma de memória implícita bastante estudada é o aprendizado emocional, isto é, as mudanças na forma como nos sentimos a respeito daquilo que foi processado pelas vias perceptuais ( $i d$. ibid.). A forma como se avalia a informação é, em grande parte, produto inconsciente (não-declarativo) do aprendizado. Apresenta-se determinado sentimento em relação aos mais variados estímulos, como um alimento, um lugar ou um cheiro, ou a qualquer outro estímulo supostamente neutro, em decorrência das experiências tidas no passado em relação a aos mesmos estímulos neutros. A biologia do aprendizado emocional tem sido intensamente estudada em laboratório. Experimentos mostram que o medo aprendido, por exemplo, não é eliminado com lesões do hipocampo, mas com lesões bilaterais da amígdala.

Sabe-se que a amígdala é importante para a aquisição de memórias baseadas no medo e em outras emoções, mas não se sabe se as próprias memórias são armazenadas nessa estrutura. O que é certo é que a amígdala parece ser o centro de um eixo relacionado à aquisição e expressão de memórias implícitas envolvendo eventos emocionais, tanto positivos quanto negativos.

As habilidades motoras adquiridas também constituem exemplo de memória implícita. Essas habilidades, como tocar piano, dirigir ou jogar tênis, são impregnadas de procedimentos, expressos por meio do desempenho. Para que o desempenho ocorra, no entanto, não há necessidade de que se lembre deles verbalmente. Experimentos mostram que a tentativa de lembrar-se do procedimento enquanto o executamos é uma bela maneira de prejudicar o desempenho de uma tarefa. Estudos com imagens mostram que diversas áreas do encéfalo são ativadas durante o aprendizado de habilidades, incluindo o córtex sensório-motor, o núcleo caudado e o putâmen (estes dois últimos juntos formam o neoestriado).

Ao adquirir habilidade motora nova, adquire-se procedimento para operar no ambiente. O mesmo pode ser válido para a aquisição de hábitos novos. Ao longo da vida, o ser humano aprende hábitos que logo se tornam automáticos, como dizer "obrigado" e "por favor" ou lavar as mãos antes das refeições. Todos os hábitos automáticos são exemplos de memórias não-verbais, ou seja, implícitas. É difícil fazer pesquisas neurocientíficas sobre hábitos humanos, pois tendemos a memorizar cada passo de uma tarefa de forma verbal. Pesquisas em outros animais, no entanto, como ratos e macacos, sugerem que aqui, mais uma vez, o estriado e o núcleo caudado têm papel central.

Mas, o exemplo mais importante de memória implícita é o condicionamento clássico, ou pavloviano, em que um estímulo neutro precede a apresentação de um estímulo biologicamente significativo, como alimento ou choque elétrico. Esse tipo de condicionamento é importante por estar disseminado pela natureza, pois é, basicamente, dessa forma que os animais aprendem sobre relações de causa e efeito em seu ambiente. $\mathrm{O}$ tipo de aprendizado fornecido pelo condicionamento 
pavloviano continua intacto em pacientes amnésicos e em animais com lesões no hipocampo. Squire e Kandel ressaltam que esse tipo de condicionamento é possível mesmo em animais que tiveram todo o prosencéfalo retirado.

Há várias formas de proceder-se ao condicionamento pavloviano. A mais utilizada é o condicionamento com retardo, em que o estímulo condicionado neutro (CS) é apresentado juntamente e depois do estímulo incondicionado (US). O fator tempo é muito importante, pois qualquer intervalo entre o CS e o US implicará a necessidade de outros mecanismos de memória para que o condicionamento ocorra. Assim, se houver um tempo entre o CS e o US, o sujeito deverá ser capaz de armazenar e lembrar o CS para que o condicionamento ocorra. (Catania, 1999) Estudos feitos com animais sugerem que, no condicionamento, sempre está implicada a área responsável pelo comportamento condicionado - motor, por exemplo - e mais o cerebelo, que, de acordo com Squire e Kandel, parece ser o órgão responsável pelo controle da percepção de fluxo do tempo nos animais.

No caso de haver intervalo entre os dois estímulos, o condicionamento é chamado de condicionamento clássico de traço, em alusão à necessidade de haver um traço de memória no indivíduo para que haja condicionamento. Essa pequena variação cria situação nova, e experimentos mostram que indivíduos com falhas hipocampais falham na aquisição desse condicionamento.

Infere-se dos experimentos realizados que, para o condicionamento de traço ocorrer, é necessário que o indivíduo tenha perfeitas condições em sua memória declarativa. Isso, provavelmente, acontece porque o intervalo de tempo interrompe a ligação automática entre os dois estímulos. Como CS e US não são contíguos, só pela memória explícita pode-se fazer a ligação entre os dois.

\section{Conclusão}

A história do estudo da memória confunde-se com a história da psicologia de tal forma que ninguém pode negar o quanto é inestimável a contribuição dos pesquisadores e teóricos da memória para que a psicologia atingisse a posição que ocupa, capaz de enriquecer qualquer debate teórico sobre a natureza do homem, de participar de qualquer pesquisa científica que investigue a cognição humana, de dialogar em igualdade de condições com qualquer das disciplinas com as quais faz fronteiras, como lingüística, sociologia, antropologia, biologia, neurociência, ciência política e ciência da computação, entre outras. Uma simples olhada nessa história deixa ver que, hoje, sabe-se muito mais sobre a memória que nos tempos de, por exemplo, Platão ou Aristóteles, ambos geniais cognitivistas avant la lettre. 
Por impressionante que seja esse quadro, não se pode negar o fato de que o conhecimento atual é apenas uma sombra pálida do que ainda aguarda para ser descoberto.

O que se pode fazer? Talvez realçar o que se sabe e congratularmo-nos. Quem sabe, dar mais importância ao desconhecido e remoer nossa ignorância. A história das ciências mostra que o caminho a ser seguido não é nem um, nem outro. Qualquer ciência, a psicologia, cresce toda vez que duvida de si mesma, que se coloca à prova. É isso o que tem sido feito e assim deve ser para sempre, a bem da própria psicologia. Com o estudo da memória, em especial, esse caminho mostra-se muito produtivo. Dos últimos cinco prêmios Nobel de Fisiologia e Medicina, dois - o de 2000 e o de 2004 - foram conferidos a pesquisas cujo tema central era a memória.

Não obstante, houve-se por bem apontar que algum processo, mental ou físico, ainda não era inteiramente conhecido. A memória humana aguarda ser totalmente desvendada, e isso passa necessariamente por estudos baseados na genética, na dimensão dos sistemas de memória que, por sua vastidão e complexidade extremas, não foram contempladas neste trabalho.

Sigmund Freud, de forma pouco modesta, afirmou que o homem, em toda sua história, havia sofrido apenas três grandes golpes em sua infinita vaidade: o primeiro, desferido por Copérnico, que retirou a Terra do centro do Universo; o segundo, por Darwin, que retirou o homem do centro da natureza; e o terceiro, por ele próprio, Freud, que, com a psicanálise, retirou o homem do centro de sua própria consciência. Cem anos depois das palavras de Freud, Copérnico é uma realidade científica incontestável, e é cada vez mais difícil, a despeito dos fundamentalistas religiosos, posicionar-se contra Charles Darwin. Quanto ao terceiro golpe, ninguém duvida de que foi desferido, mas não pela psicanálise e, sim, pela psicologia cognitiva e pela neurociência, que, juntas, mostraram como e por que o ser humano é capaz de conhecer, inclusive a si mesmo. E, o entendimento de como a memória funciona contribuiu e contribuirá sobremaneira para isso.

\section{Referências}

Abbagnano, N. (2000). Dicionário de filosofia. São Paulo. Martins Fontes.

Anderson, J. R. (2004). Psicologia cognitiva e suas implicações experimentais. 5. ed.

Rio de Janeiro: LTC. 2004.

Bear, M. F., Connors, B. W. \& Paradiso, M. A. (2002). Neurociências: desvendando o sistema nervoso. Porto Alegre: Artmed.

Campbell, J. (1991). O poder do mito. São Paulo: Palas Athena. 
Catania, A. C. (1999). Aprendizagem: comportamento, linguagem e cognição. 4. ed. Porto Alegre: Artmed.

Chauí, M. (1995). Convite à filosofia. 5. ed. São Paulo: Ática.

Damásio, A. (1996). O erro de Descartes. São Paulo: Companhia das Letras.

— - (2001). O mistério da consciência. São Paulo: Companhia das Letras.

Durant, W. (1996). A história da filosofia. São Paulo: Nova Cultural.

Eliade, M. (1998). Tratado de história das religiões. São Paulo: Martins Fontes.

Everdell, W. R. (2000). Os primeiros modernos. Rio de Janeiro: Record.

Ghiraldelli Jr., P. (2002). Introdução à filosofia. São Paulo: Manole.

Gleitman, H., Fridlund, A. J. \& Reisberg, D. (2003). Psychology. 6. ed. New York: W. W.

Norton \& Company.

Guyton, A. C. \& Hall, J. E. (1996). Tratado de fisiologia médica. Rio de Janeiro:Guanabara Koogan.

Hegel, G. W. F. (1991). Introdução à história da filosofia. Lisboa: Edições 70.

Izquierdo, I. (2004). A arte de esquecer. Rio de Janeiro: Vieira \& Lent.

Kandel, E. R.; Schwartz, J. H. \& Jessell, T. M. (2000). Fundamentos da neurociência e do comportamento. Rio de Janeiro: Guanabara Koogan.

- (2003). Princípios de Neurociência. São Paulo: Manole.

Lent, R. (2001). Cem bilhões de neurônios: conceitos fundamentais de neurociência. São Paulo: Atheneu. 2001.

May, R. (1992). A procura do mito. São Paulo: Manole.

Mondin, B. (1980). Introdução à filosofia: problemas, sistemas, autores, obras. São

Paulo: Edições Paulinas.

— . (1983). Curso de filosofia. São Paulo: Paulus. 1981. Vols. 1 e 3.

Nagel, T. (2001). Uma breve introdução à filosofia. São Paulo: Martins Fontes.

Nagel, T. (2004). Visão a partir de lugar nenhum. São Paulo: Martins Fontes.

Padovani, H. \& Castagnola. (1967). História da filosofia. $7^{\text {a }}$. ed. São Paulo: Melhoramentos.

Pinker, S. (2004). Tábula rasa: a negação contemporânea da natureza humana. São Paulo: Companhia das Letras.

Popper, K. R. \& Eccles, J. C. (1995). O eu e seu cérebro. Campinas: Papirus.

Sagan, C. (1985). Os dragões do Eden. Rio de Janeiro: Francisco Alves.

Searle, J. R. (1997). A redescoberta da mente. São Paulo: Martins Fontes.

Shultz, D. (1995). História da psicologia moderna. São Paulo: Cultrix.

Squire, L. R. \& Kandel, E. R. (2003). Memória: da mente às moléculas. Porto Alegre: Artmed.

Schwab, G. (1997). As mais belas histórias da antigüidade clássica. São Paulo: Paz e Terra. 
Teixeira, J. de F. (2000). Mente, cérebro e cognição. Petrópolis: Vozes.

Tulving, E. (2002). Episodic memory: from mind to brain. Annual Review of Psychology, 53, $1-25$.

Wheeler, M. A., Stuss, D. T. \& Tulving, E. (1997). Toward a theory of episodic memory: the frontal lobes and autonoetic consciousness. Psychological Bulletin, 121, 3, 331-354.

Yates, F. (1966). The art of memory. Chicago: University of Chicago Press. 